\title{
Is the idea of human rights a universal concept?
}

\section{Laksshini Sundaramoorthy}

\section{Abstract}

While human rights is not a universal concept, its construction as a form of Western cultural imperialism represents an unfounded and inaccurate reading of civilisation. The idea of human rights as an entitlement of every human being, with an unqualified universal scope, is somewhat unattainable as variations in conceptions of justice are inevitable. However, the assertion that human rights are imposed by the West and would otherwise hold no resonance in non-Western societies, overstates the uniqueness of human rights to Western culture. Rather, there is an 'overlapping consensus' in that the acceptance and recognition of human rights is not complete but partial. While its principles cannot possibly be applicable to all state priorities and behaviour, the general concept of justice, at a higher level of abstraction, transcends cultural boundaries and is not solely confined to Western society. This notion is demonstrated through an examination of Islamic culture and Sharia law.

\section{Introduction}

In response to this contentious issue, two prominent schools of thought have emerged: unilateral universalism and cultural absolutism. Proponents of unilateral universalism, most notably Tharoor in 'Are Human Rights Universal?', concedes that human rights are derived from a shared faith in 
humanity and cultural considerations become immaterial. ${ }^{1}$ On the other end of the spectrum, cultural absolutists like Ibhawoh describe human rights as one particular culture being imposed upon the entire world in a form of neo-imperialism. ${ }^{2}$ Unlike traditional approaches that consider the absence of universality and Western cultural imperialism as interchangeable and consequences of one another, this essay will investigate the nuances between these two extreme positions. By considering each proposal in isolation of one another, the inherent flaws of both arguments will become apparent. This will warrant the conceptualisation of an overlapping consensus.

\section{A universal standard}

The presumption of universal human rights, in its demanding form, is somewhat unachievable as states will inevitably vary in their perception of justice. As rights are defined by the value systems adopted by states, the absence of a homogenous moral community defeats universalist arguments. In other words, the diversity of moral systems means that states will obviously designate and place emphasis on different aspects of justice. The mere assertion of a universal standard conjures philosophical questions of "whether anything in our pluri-cultural, multipolar world can be truly universal?'3 According to Donnelly, theories stemming from such a 'perverse' and 'arrogant' unilateral universalism fail to consider the nature of international diversity. ${ }^{4}$ Therefore, the universality of human rights is largely undermined by the variety of moral systems in the international sphere.

The cause for such variations can be attributed to certain states prioritising collective needs over individual human rights. The concept of human rights is founded on inalienable, indivisible rights that are innate to all human beings. This presents a host of complexities in communal cultures, where individual rights are viewed only as duties that a person has to the group. For example, in Chinese Confucianism, individual entitlements are inherently intertwined

\footnotetext{
1 Shashi Tharoor. 1999/2000. 'Are Human Rights Universal?' World Policy Journal XVI(4) Winter.

2 B. Ibhawoh. 2007. Imperialism and Human Rights: Colonial Discourses of Rights and Liberties in African History. New York: SUNY Press.

3 Shashi Tharoor, 'Are Human Rights Universal?'.

4 J. Donnelly. 2007. 'The Relative Universality of Human Rights.' Human Rights Quarterly 29(2): 305.
} 
with communal duties: 'I am because we are, and because we are therefore I am'. ${ }^{5}$ Moreover, despite violating various human rights, the practice of female circumcision in African cultures is an indispensable prerequisite to marriage and an estial component of a woman's traditional role within her community. ${ }^{6}$ Thus, the individualistic themes embedded in human rights often conflict with the communitarian ethic that characterises traditional societies.

\section{Western cultural imperialism}

Nonetheless, a lack of universality does not equate human rights to Western cultural imperialism. By portraying human rights as unique to Western states, cultural absolutists depend upon unsubstantiated claims of 'clashing civilisations' 7 This falsely implies that the West alone have arrived at the paradigmatic principles contained within the Universal Declaration of Human Rights (UDHR) and such ideas fall outside the trajectory of non-Western civilisations. Viewing international relations as a binary relationship between the West and the non-West incorrectly subsumes all members of society under a generalised and inaccurate framework. Sen argues that oversimplifications about 'Western civilisation', 'Asian values', 'African cultures' and so on are not only unfounded readings of history, but also add to the divisiveness of the world. ${ }^{8}$ Therefore, considering human rights as Western imperialism assumes a cultural dichotomy that simply does not exist.

The absence of clashing civilisations is a result of 'cross-cultural fertilisation', where human rights ideals are not localised to specific geographic regions or societies. The intellectual movements associated with the West have multiple and diverse foundations as cultures are not 'sealed boxes but a fertile jungle of different sources. ${ }^{9}$ For instance, although often accredited to an outcome of Western liberalism, the language of freedom is a key tenet of Buddhism

5 J. Young Lee. 1984. Marginality: The Key to Multicultural Theory. Minneapolis: Fortress Press, p. 31.

6 G. Gallo, P. Hodges and M.F. Vivani. 2006. Bodily integrity and the politics of Circumcision. New York: Springer Publishing.

7 S.P. Huntington. 1961. The Clash of Civilisations and the Remaking of World Order. New York: Simon \& Schuster, p. 1.

8 A. Sen. 1998. Universal Truths: Harvard International Law Review. Massachusetts: Harvard University Press.

9 M. Midgely. 1981. Trying out one's new sword. New York: Palgrave McMillan, p. 2. 
and can, by extension, be seen to originate in South-East Asia. Similarly, a plethora of contemporary Indian literature has represented the Hindu caste hierarchy as a multidimensional system of human rights. ${ }^{10}$ The enduring (not universal) relevance of human rights to non-Western states is exemplified by Donnelly, who proposes that even if a value or practice emerged in place $\mathrm{A}$, it is a dubious philosophical claim to assume its complete inapplicability to place B. ${ }^{11}$ As a result, human rights should not be viewed as Western imperialism because doing so would deny recognition of its multicultural sources.

\section{Overlapping consensus}

The overlapping consensus is an alternative and more moderate explanation that lies between these two extreme standpoints. The term, coined by John Rawls in his development of political liberalism, can be viewed as the 'political and philosophical equivalent of the Venn diagram framework'. ${ }^{12}$ It illustrates how supporters of conflicting normative doctrines can somehow agree on particular ideas or arguments. The commonality of values doesn't imply universality but rather a coincidental overlap. Hence, the concept of overlapping consensus provides a platform for which the competing claims of universalism and cultural relativism can be reconciled.

Applying this theory to human rights reveals the obvious discrepancies, as well as the similarities, between the two opposing schools of thought. On one hand, the universal standard of human rights is unattainable as different states will inevitably adopt different moral systems. On the other hand, the interpretation of human rights as a product of Western imperialism is implausible because the idea did not originate from any exclusive Western cultural roots. The space in which these two competing conjectures converge, or the point of intersection on the Venn diagram, is the political conception of justice underpinning human rights. That is, although this conception of justice produces different meanings for different states, the recognition of a need to achieve justice is pervasive throughout the world and is not bound

10 J. Donnelly, 'The Relative Universality of Human Rights', p. 295.

11 Ibid.

12 G. Forster and A. Bradley. 2014. John Rawls and Christian Social Engagement: Justice as Unfairness. Maryland: Lexington Books, p. 20. 
to a particular culture. Thus, the overlapping consensus captures the often neglected 'grey area' of human rights and moves beyond a dichotomous presentation of the issue.

\section{Case study: Islamic culture and Sharia law}

Islamic culture represents an alternative value system that is, to some extent, incompatible with human rights. For instance, the penalties available under Sharia criminal law are considered cruel and clearly contravene Article 5 of the UDHR. According to Islamic culture, these inhumane punishments, such as flogging and the amputation of limbs, are viewed as a necessary component of social order. Another point of conflict between human rights and Sharia law is that the rights of women are restricted to traditional duties owed to the family rather than being individualistic in nature. This is exemplified by Abu Huraira (a companion to the Prophet Muhammad), who stated that a woman's duties, and thereby her rights are confined to the 'care of her young ones and the protection of her husband's property'. ${ }^{13}$ Hence, Islamic culture diverges from human rights and simultaneously disproves the presumption of universalism.

However, while Sharia law does divert from human rights, Islamic culture has consistently promoted the idea of justice and is not entirely detached from liberalist thinking often associated with the West. Paralleling the 'right to life' enshrined in the UDHR, the Quran upholds the sanctity of human life as it is considered a divine bestowal on humanity that should be secured by all means. ${ }^{14}$ Moreover, the Islamic concept of Adl reflects themes expressed within human rights doctrines as it stipulates 'fairness in everything a person does. ${ }^{15}$ The freedom of religion is also protected through a number of Quranic passages, which clearly state that the responsibility of Prophet Muhammad is to communicate the message of God and not to compel anyone to believe: 'those who follow the Jewish and the Christians and the Sabians ... shall (have) no fear, nor shall they grieve'. ${ }^{16}$ Furthermore, verse 24:27 of the Quran recognises privacy as a human right and outlines rules that safeguard an

13 M. Al Bukhari. 854. Sahih al-Bukhari, n/a, 278.

14 I. Ali. 632. The Quran, Mashhad, Iran.

15 H. Beilefeldt. 2000. "Western” versus "Islamic" Human Rights Conceptions?: A Critique of Cultural Essentialism in the Discussion on Human Rights.' Political Theory 28(1): 117.

16 Ali 632, verse 2:62. 
individual's home life from undue intrusion. ${ }^{17}$ Therefore, as evidenced from the above examples, Sharia law is not completely dislocated from human rights ideals.

By applying the concept of overlapping consensus to Sharia law, the relative acceptance of human rights in Islamic states can be explained. Sharia law diverges from human rights in that responsibilities to the community supersede the human rights innate to individuals. However, Islamic culture has also promoted values consistent with the UDHR, such as freedom, fairness and tolerance. Instead, there is an overlapping consensus: while the ideals promoted by Islamic culture do not completely align with those contained in human rights, there is a broader conception of 'divine justice' in which morality is sanctioned by the Quran and other religious traditions. As a result, the theory of overlapping consensus accounts for the incomplete but partial recognition of human rights in Islamic states.

\section{Conclusion}

After examining the key aspects of this debate and analysing the role of human rights in Islamic culture, it is evident that the idea of human rights is neither universal nor does it represent Western cultural imperialism. The assumption of universalism is undermined by certain states prioritising collective needs over individual rights. However, cross-cultural fertilisation means that human rights also fail to represent Western cultural imperialism as the ideals are applicable to non-Western states as well. Instead, there is an overlapping consensus where the political conception of justice, whatever that conception may be, is internationally recognised.

\section{References}

Al Bukhari, M. 854, Sahih al-Bukhari, n/a.

Ali, I. 632. The Quran, Mashhad Iran.

17 Ibid. 
Beilefeldt, H. 2000. “"Western” versus “Islamic” Human Rights Conceptions?: A Critique of Cultural Essentialism in the Discussion on Human Rights.'Political Theory 28(1). doi.org/10.1177/0090591700028001005.

Donnelly, J. 2007. 'The Relative Universality of Human Rights.' Human Rights Quarterly 29(2): 281-306.

Forster, G. and A. Bradley 2014. John Rawls and Christian Social Engagement: Justice as Unfairness. Maryland: Lexington Books.

Gallo, G., P. Hodges and M.F. Vivani 2006. Bodily integrity and the politics of Circumcision. New York: Springer Publishing.

Huntington, S.P. 1961. The Clash of Civilisations and the Remaking of World Order. New York: Simon \& Schuster.

Ibhawoh, B. 2007. Imperialism and Human Rights: Colonial Discourses of Rights and Liberties in African History. New York: SUNY Press.

Lee, J. Young 1984. Marginality: The Key to Multicultural Theory. Minneapolis: Fortress Press.

Midgely, M. 1981. Trying out one’s new sword. New York: Palgrave McMillan.

Rawls, J. 1971. A Theory of Justice. Cambridge: Belknap Press.

Sen, A. 1998. Universal Truths: Harvard International Law Review. Massachusetts: Harvard University Press.

Tharoor, S. 1999/2000. 'Are Human Rights Universal?' World Policy Journal XVI(4) Winter. 
This text is taken from Merici, Volume 2, 2016, edited by Matthew Rogers, published 2017 by ANU eView, The Australian National University,

Canberra, Australia. 